SYSTEMATIC REVIEW

\title{
Review of the role of alcohol in drowning associated with recreational aquatic activity
}

\author{
T R Driscoll, J A Harrison, M Steenkamp
}

Injury Prevention 2004;10:107-113. doi: 10.1136/ip.2003.004390

See end of article for authors' affiliations ar.

Correspondence to: Dr Timothy R Driscoll, ELMATOM Pty Ltd, 49 Taleeban Road, Riverview, NSW 2066, Australia; elmatom@optushome. com.au
Objective and design: To assess the role of alcohol in drowning associated with recreational aquatic activity by reviewing the English language literature published up to October 2003.

Results: Alcohol is widely used in association with recreational aquatic activity in the United States, but there is minimal information regarding the extent of use elsewhere. A priori and anecdotal evidence suggests that alcohol is an important risk factor for drowning associated with recreational aquatic activity. Specific studies provide good evidence supporting this, but the extent of increased risk associated with alcohol use, and the attributable risk due to alcohol use, is not well characterised. Drowning appears to be the overwhelming cause of death associated with recreational aquatic activity with alcohol detected in the blood in 30\%-70\% of persons who drown while involved in this activity. The few relevant studies on degree of increased risk suggest persons with a blood alcohol level of $0.10 \mathrm{~g} / 100 \mathrm{ml}$ have about 10 times the risk of death associated with recreational boating compared with persons who have not been drinking, but that even small amounts of alcohol can increase this risk. The population attributable risk seems to be in the range of about $10 \%-30 \%$.

Conclusions: Alcohol consumption significantly increases the likelihood of immersions resulting in drowning during aquatic activities. However, more information is required if appropriate prevention activities are to be planned, initiated, and evaluated. This includes better information on alcohol use, and attitudes to alcohol use, in association with recreational aquatic activity, and the nature and extent of increased risk associated with alcohol use. Evaluation of interventions is also needed.
$\mathrm{D}$ rowning is a major cause of death worldwide, estimated to have caused 450000 deaths in $2000 .^{1}$ Recreational aquatic activity (such as swimming and boating) is commonly associated with drowning, ${ }^{23}$ and alcohol has been implicated as a significant contributing factor in many drowning cases. ${ }^{4-6}$

This paper reviews the literature in order to synthesise the available information regarding the role of alcohol in drowning associated with recreational aquatic activity, in particular to inform the development of appropriate interventions.

\section{METHODS}

English language literature published up to October 2003 was searched for relevant articles. The main keywords used were "drown", "drowning", "immersion", "alcohol", "drink", and "drinking". Initial searches were through PubMed ${ }^{7}$ and the library of the Research Centre for Injury Studies. Secondary follow up of sources cited in reference lists of obtained papers also provided a number of appropriate papers.

Recreational aquatic activities were defined as activities explicitly related to water that are undertaken for fun, pleasure or amateur sport, and included swimming, surfing, boating, water skiing, underwater diving, and fishing. Any relevant setting was included, such as oceans, beaches, rivers, creeks, lakes, and public and private swimming pools. Drowning deaths that occurred as result of swimming activity were examined separately to those during boating. Deaths that occurred when the contact with the water was incidental (such as falling in while walking near water), or the activity was not recreational (such as washing in a bathtub or working on a vessel), were excluded as much as possible. In practice, this was usually possible if enough information was included in the paper, but it was sometimes difficult to exclude all unwanted cases because of the way the data were presented in the available papers and reports. Similarly, it was sometimes difficult to confidently identify a subgroup of cases that only included swimming. Relevant methodological aspects of the study, including the extent to which the relevant subjects were only engaged in recreation, the definition used by the study of the activities equivalent to "swimming" or "boating", the age of the subjects included in the part of the study relevant to consideration of the involvement of alcohol, the number of subjects in the relevant group, and the number (and proportion) of subjects with valid blood alcohol readings, are included in the study summaries presented in tables 1 and 2 .

\section{METHODOLOGICAL CONSIDERATIONS}

Physiological and psychological effects of alcohol

Physiological and psychological effects of alcohol have potential to increase the risk of immersion injury for persons involved in swimming and other water related activity because they increase the likelihood of exposure to high risk situations, and the harm that might result, by affecting cognitive processing, central nervous system processing, and physiological responses. In particular, impaired judgment increases the likelihood of persons choosing to be, or not avoiding being, exposed to higher risk situations; blood vessel dilatation increases the period of time someone may choose to remain in cold water, thereby increasing the risk of sustaining hypothermia; and labyrinthine dysfunction and laryngospasm decrease the chances of survival if in the water. These factors can also increase the difficulties facing any potential rescuer. ${ }^{5-12}$

Abbreviations: $\mathrm{Cl}$, confidence interval; $\mathrm{RR}$, relative risk 
Table 1 Alcohol involvement in deaths arising from recreational swimming: summary of results from main studies

\begin{tabular}{|c|c|c|c|c|}
\hline Country and years & Population* & Swimmingt & & Alcohol determination criteria \\
\hline $\begin{array}{l}\text { United States (New York), 1988-94; } \\
\text { Browne et al, 2003² }\end{array}$ & $\begin{array}{l}\text { All unintentional drownings } \\
\text { Persons } \geqslant 15 \text { years; "swimming" }\end{array}$ & $\begin{array}{l}n=214 \\
\text { More than zero } \\
>0.05 \\
>0.10\end{array}$ & $\begin{array}{l}49 \% \\
40 \% \\
35 \%\end{array}$ & $\begin{array}{l}\text { Death within } 6 \text { hours; blood taken with } \\
24 \text { hours of death } \\
\text { Available for } 111 \text { (52\%) }\end{array}$ \\
\hline $\begin{array}{l}\text { United States (California), 1974-85; } \\
\text { Wintemute et al, } 1988^{32}\end{array}$ & $\begin{array}{l}\text { All drownings } \\
\text { Persons } \geqslant 20 \text { years; "swimming, } \\
\text { wading, diving" }\end{array}$ & $\begin{array}{l}n=73 \\
\text { More than zero } \\
>0.05 \\
>0.10\end{array}$ & $\begin{array}{l}63 \% \\
55 \% \\
40 \%\end{array}$ & $\begin{array}{l}\text { Death within } 6 \text { hours; blood taken with } \\
24 \text { hours of death } \\
\text { Available for } 40 \text { (55\%) }\end{array}$ \\
\hline $\begin{array}{l}\text { Canada, 1999; Canadian Red Cross } \\
\text { Society, 2000 }\end{array}$ & $\begin{array}{l}\text { All drowning deaths } \\
\text { Persons } \geqslant 15 \text { years; } \\
\text { "recreational swimming" }\end{array}$ & $\begin{array}{l}\mathrm{n}=58 \\
\text { More than zero } \\
>0.08\end{array}$ & $\begin{array}{l}63 \% \\
53 \%\end{array}$ & $\begin{array}{l}\text { "Blood testing" } \text {-no more details } \\
\text { Available for } 40 \text { (69\%) }\end{array}$ \\
\hline $\begin{array}{l}\text { United States (Maryland), 1968-72; } \\
\text { Dietz and Baker } 1974^{34}\end{array}$ & $\begin{array}{l}\text { "Accidental" drownings } \\
\text { Persons } \geqslant 15 \text { years; "swimming" }\end{array}$ & $\begin{array}{l}\mathrm{n}=\text { ? (total number } \mathrm{n} \\
\text { More than zero } \\
>0.10 \\
>0.15\end{array}$ & $\begin{array}{l}\text { ot known) } \\
79 \% \\
64 \% \\
50 \%\end{array}$ & $\begin{array}{l}\text { "Blood tests"; body submerged less than } \\
12 \text { hours } \\
\text { Available for } 14 \text { (unknown \%) }\end{array}$ \\
\hline $\begin{array}{l}\text { Australia (Geelong), 1959-83; } \\
\text { Plueckhahn, 1984 }\end{array}$ & $\begin{array}{l}\text { "Accidental" drownings } \\
\text { Persons } \geqslant 15 \text { years; } \\
\text { "swimming or surfing" }\end{array}$ & $\begin{array}{l}\mathrm{n}=\text { ? (total number } \mathrm{n} \\
\text { More than zero } \\
\geqslant 0.08 \\
\geqslant 0.15\end{array}$ & $\begin{array}{l}\text { ot known) } \\
37 \% \\
16 \% \\
16 \%\end{array}$ & $\begin{array}{l}\text { "Valid" blood alcohol levels in autopsy blood } \\
\text { sample } \\
\text { Available for } 43 \text { (unknown \% of swimming } \\
\text { deaths, but available for } 61 \% \text { of all drownings) }\end{array}$ \\
\hline $\begin{array}{l}\text { Australia (Geelong), 1967-71; } \\
\text { Plueckhahn, 1972 }\end{array}$ & $\begin{array}{l}\text { "Accidental" drownings } \\
\text { Persons } \geqslant 16 \text { years; } \\
\text { "swimming, etc" }\end{array}$ & $\begin{array}{l}n=? \text { (total number } n \\
\text { More than zero } \\
\geqslant 0.08 \\
\geqslant 0.15\end{array}$ & $\begin{array}{l}\text { ot known) } \\
43 \% \\
36 \% \\
36 \%\end{array}$ & $\begin{array}{l}\text { "Valid" blood alcohol levels in autopsy blood } \\
\text { sample } \\
\text { Available for } 14 \text { (unknown \% of swimming } \\
\text { deaths, but available for } 69 \% \text { of all drownings) }\end{array}$ \\
\hline $\begin{array}{l}\text { South Africa (Cape Town), 1980-83; } \\
\text { Davis and Smith, } 1985^{37}\end{array}$ & $\begin{array}{l}\text { All drownings } \\
\text { Persons } \geqslant 16 \text { years; "swimming" }\end{array}$ & $\begin{array}{l}\mathrm{n}=87 \\
\text { More than zero }\end{array}$ & $55 \%$ & $\begin{array}{l}\text { Alcohol present in autopsy blood sample } \\
\text { Available for } 87(100 \%)\end{array}$ \\
\hline $\begin{array}{l}\text { United States (North Carolina), } \\
\text { 1980-84; Patetta and Biddinger, } \\
1988^{38}\end{array}$ & $\begin{array}{l}\text { Unintentional drownings } \\
\text { Persons } \geqslant 15 \text { years; } \\
\text { "swimming and wading" }\end{array}$ & \multicolumn{2}{|c|}{$\begin{array}{l}n=? \text { (total number not known) } \\
>0.10 \quad>20 \%\end{array}$} & $\begin{array}{l}\text { Alcohol present in autopsy blood sample } \\
\text { Available for an unknown \% of swimming } \\
\text { deaths, but for } 87 \% \text { of all drownings }\end{array}$ \\
\hline $\begin{array}{l}\text { United States (army soldiers), } \\
\text { 1980-97; Bell et al, 2001 }\end{array}$ & $\begin{array}{l}\text { Non-intentional drownings } \\
\text { Active male soldiers } \\
\geqslant 18 \text { years; } 83 \% \text { associated } \\
\text { with recreation, particularly } \\
\text { swimming }(40 \%) \text {, boating } \\
(15 \%) \text { and diving }(6 \%)\end{array}$ & \multicolumn{2}{|l|}{$\begin{array}{l}\mathrm{n}=352 \\
\text { "Contributed" to } \\
31 \% \text { of all cases, and } \\
58 \% \text { of cases with } \\
\text { information on blood } \\
\text { alcohol }\end{array}$} & $\begin{array}{l}\text { Alcohol information obtained from investigative } \\
\text { reports. No blood alcohol values presented. } \\
\text { Available for } 187 \text { (53\%) }\end{array}$ \\
\hline $\begin{array}{l}\text { Denmark, 1989-93; } \\
\text { Steensberg, 1998 }\end{array}$ & $\begin{array}{l}\text { "Accidental" drowning deaths } \\
\text { Persons } \geqslant 15 \text { years; } \\
\text { "bathing or swimming" }\end{array}$ & $\begin{array}{l}\mathrm{n}=33 \\
\text { "Under the } \\
\text { influence" }\end{array}$ & $36 \%$ & $\begin{array}{l}\text { Information on alcohol involvement from the } \\
\text { death certificate summary } \\
\text { Available for an unknown \% of swimming } \\
\text { deaths }\end{array}$ \\
\hline
\end{tabular}

\section{Assessing the contribution of alcohol}

Several factors need to be considered when assessing the evidence for a causal or contributory role for alcohol in drowning associated with recreational aquatic activity. A key consideration is whether alcohol relatedness/involvement refers solely to the "presence of alcohol", or to whether alcohol "contributed to" or "caused" the injury event because of impairment of relevant parties. Confounding factors (for example, polydrug use, how learned the activity is, hangover effects, and psychophysiological consequences) complicate the relationship between intoxication and impairment further. "Alcohol relatedness" can also refer to alcohol use by other parties involved in the injury event, such as a boat operator when a passenger drowns, although information on this type of alcohol relatedness is rarely collected routinely.

It is, in principle, possible to assess injured people, case by case, to determine whether alcohol might have contributed to the occurrence of each injury case. That can be done by obtaining evidence that the injured person, or some other person involved in the event that resulted in injury, had a significant level of blood alcohol at the time of occurrence, and that the circumstances of the incident were such that it was likely that the level of intoxication of the person contributed to the injury occurring and/or to the resulting injury being more serious than it might otherwise have been. However, the necessary level of information is often lacking. ${ }^{13}$

Another important consideration is the fact that blood alcohol levels can rise after death due to decomposition processes, or fall before death due to normal metabolic processes. Therefore, it is important to obtain information regarding when the blood used for blood alcohol level estimation is taken in relation to both the incident and the death. ${ }^{14-17}$ Various criteria for this have been suggested. ${ }^{18}{ }^{19}$

\section{RESULTS}

\section{Use of alcohol in recreational aquatic activities}

Most information on the use of alcohol in association with recreational water activity comes from telephone surveys or face-to-face interviews conducted in the United States, either at a national or state level. These surveys have consistently 
Table 2 Alcohol involvement in deaths arising from recreational boating: summary of results from main studies

\begin{tabular}{|c|c|c|c|c|}
\hline Country and years & Population* & Boatingt & & Alcohol determination criteria \\
\hline $\begin{array}{l}\text { United States (New York), 1988-94; } \\
\text { Browne ef al, } 2003^{40}\end{array}$ & $\begin{array}{l}\text { All unintentional drownings } \\
\text { Persons } \geqslant 15 \text { years; water craft } \\
\text { related ( }>90 \% \text { recreational) }\end{array}$ & $\begin{array}{l}\mathrm{n}=207 \\
\text { More than zero } \\
>0.05 \\
>0.10\end{array}$ & $\begin{array}{l}44 \% \\
33 \% \\
25 \%\end{array}$ & $\begin{array}{l}\text { Death within } 6 \text { hours; blood taken with } \\
24 \text { hours of death } \\
\text { Available for } 73(35 \%)\end{array}$ \\
\hline $\begin{array}{l}\text { United States (Louisiana), 1998; } \\
\text { CDC, } 2001^{41}\end{array}$ & $\begin{array}{l}\text { All drownings } \\
\text { Persons } \geqslant 13 \text { years; "boating } \\
\text { related" }(<10 \% \text { occupational) }\end{array}$ & $\begin{array}{l}n=34 \\
\text { More than zero }\end{array}$ & $48 \%$ & $\begin{array}{l}\text { Alcohol (and/or drugs) present in autopsy } \\
\text { sample } \\
\text { Available for } 27(79 \%)\end{array}$ \\
\hline $\begin{array}{l}\text { United States (Maryland and North } \\
\text { Carolina), 1990-98; Smith et al, } \\
2001^{28}\end{array}$ & $\begin{array}{l}\text { Recreational boating fatalities } \\
\text { (nearly all drowned) occurring } \\
\text { from April to October inclusive } \\
\text { Persons } \geqslant 18 \text { years }\end{array}$ & $\begin{array}{l}\mathrm{n}=253 \\
\text { More than zero } \\
>0.05 \\
>0.10 \\
>0.15\end{array}$ & $\begin{array}{l}55 \% \\
36 \% \\
27 \% \\
11 \%\end{array}$ & $\begin{array}{l}\text { Autopsy blood alcohol levels adjusted for time } \\
\text { since death; bodies recovered within one week } \\
\text { Available for } 221 \text { (87\%) }\end{array}$ \\
\hline $\begin{array}{l}\text { United States (California), 1974-85; } \\
\text { Wintemute et al, } 1988^{32}\end{array}$ & $\begin{array}{l}\text { All drownings } \\
\text { Persons } \geqslant 20 \text { years; } \\
\text { recreational boating, rafting }\end{array}$ & $\begin{array}{l}\mathrm{n}=43 \\
\text { More than zero } \\
>0.05 \\
>0.10\end{array}$ & $\begin{array}{l}50 \% \\
35 \% \\
28 \%\end{array}$ & $\begin{array}{l}\text { Death within } 6 \text { hours; blood taken with } \\
24 \text { hours of death } \\
\text { Available for } 14(33 \%)\end{array}$ \\
\hline $\begin{array}{l}\text { Canada, 1999; Canadian Red } \\
\text { Cross Society, } 2000^{33}\end{array}$ & $\begin{array}{l}\text { All drowning deaths } \\
\text { Persons } \geqslant 15 \text { years; } \\
\text { recreational boating }\end{array}$ & $\begin{array}{l}n=116 \\
\text { More than zero } \\
>0.08\end{array}$ & $\begin{array}{l}47 \% \\
34 \%\end{array}$ & $\begin{array}{l}\text { "Blood testing" - no more details } \\
\text { Available for } 76(66 \%)\end{array}$ \\
\hline $\begin{array}{l}\text { Australia (Geelong), 1959-83; } \\
\text { Plueckhahn, 1984 }\end{array}$ & $\begin{array}{l}\text { "Accidental" drownings } \\
\text { Persons } \geqslant 15 \text { years; "water } \\
\text { transport accidents" }\end{array}$ & $\begin{array}{l}\mathrm{n}=62 \\
\text { More than zero } \\
\geqslant 0.08 \\
\geqslant 0.15\end{array}$ & $\begin{array}{r}34 \% \\
17 \% \\
3 \%\end{array}$ & $\begin{array}{l}\text { "Valid" blood alcohol levels in autopsy } \\
\text { blood sample } \\
\text { Available for } 29 \text { (47\%) }\end{array}$ \\
\hline $\begin{array}{l}\text { United States (Maryland), 1968-72; } \\
\text { Dietz and Baker, 1974 }\end{array}$ & $\begin{array}{l}\text { "Accidental" drownings } \\
\text { Persons } 15 \text { years or older, } \\
\text { "boating" }\end{array}$ & $\begin{array}{l}\mathrm{n}=? \\
\text { More than zero } \\
>0.10 \\
>0.15\end{array}$ & $\begin{array}{l}57 \% \\
43 \% \\
43 \%\end{array}$ & $\begin{array}{l}\text { "Blood tests"; body submerged less than } \\
12 \text { hours } \\
\text { Available for } 7 \text { (unknown \%) }\end{array}$ \\
\hline $\begin{array}{l}\text { United States, 2000; US Coast } \\
\text { Guard, 200142 }\end{array}$ & $\begin{array}{l}\text { "Recreational boating" fatalities } \\
\text { ( } 74 \% \text { of persons drowned) }\end{array}$ & $\begin{array}{l}\mathrm{n}=701 \\
\text { "Involved" } \\
\text { "Cause" }\end{array}$ & $\begin{array}{l}31 \% \\
14 \%\end{array}$ & $\begin{array}{l}\text { "Evidence or a reasonable likelihood that } \\
\text { alcohol was consumed by a boat's occupants" } \\
\text { Available for an unknown \% of boating deaths }\end{array}$ \\
\hline $\begin{array}{l}\text { Denmark, 1989-93; Steensberg, } \\
1998^{39}\end{array}$ & $\begin{array}{l}\text { All "accidental" drowning deaths } \\
\text { Persons } \geqslant 15 \text { years }\end{array}$ & $\begin{array}{l}\mathrm{n}=94 \\
\text { "Under the } \\
\text { influence" }\end{array}$ & $15 \%$ & $\begin{array}{l}\text { Information on alcohol involvement from } \\
\text { the death certificate summary } \\
\text { Available for an unknown \% of boating deaths }\end{array}$ \\
\hline $\begin{array}{l}\text { Finland, 1986-88; Lunetta et al, } \\
1998^{43}\end{array}$ & $\begin{array}{l}\text { Fatal leisure boat "accidents" } \\
\text { ( } 94 \% \text { of persons drowned) } \\
\text { Persons } \geqslant 15 \text { years }\end{array}$ & $\begin{array}{l}\mathrm{n}=510(340 \mathrm{dec} \\
\geqslant 0.10 \\
\geqslant 0.15\end{array}$ & $\begin{array}{l}\text { eased) } \\
\text { Operators: } 67 \% \\
\text { Passengers: } 76 \% \\
\text { Operators: } 59 \% \\
\text { Passengers: } 65 \%\end{array}$ & $\begin{array}{l}\text { Blood alcohol values probably based on blood } \\
\text { tests, but did not necessarily relate to the victim } \\
\text { (apparently sometimes being from the operator } \\
\text { of a boat from which a passenger was killed) } \\
\text { Available for } 450(88 \%)\end{array}$ \\
\hline $\begin{array}{l}\text { United States (Ohio), 1983-86; } \\
\text { Molberg et al, 199344 }\end{array}$ & $\begin{array}{l}\text { "Recreational boating" fatalities } \\
\text { ( } 80 \% \text { due to drowning) } \\
\text { Age not specified }\end{array}$ & $\begin{array}{l}n=124 \\
\text { "Mentioned" } \\
\text { "Cause" }\end{array}$ & $\begin{array}{r}21 \% \\
7 \%\end{array}$ & $\begin{array}{l}\text { Judgment about alcohol use by investigators- } \\
\text { minimal toxicological testing } \\
\text { Available for an unknown \% of boating } \\
\text { deaths }\end{array}$ \\
\hline $\begin{array}{l}\text { United States (North Carolina), } \\
\text { 1980-84; Patetta and Biddinger, } \\
1988^{38}\end{array}$ & $\begin{array}{l}\text { Unintentional drownings } \\
\text { Persons } \geqslant 15 \text { years; } \\
\text { "motorboating" }\end{array}$ & \multicolumn{2}{|c|}{$\begin{array}{l}n=? \text { (total number not known) } \\
>0.10 \quad>20 \%\end{array}$} & $\begin{array}{l}\text { Alcohol present in autopsy blood sample } \\
\text { Available for an unknown \% of boating deaths, } \\
\text { but for } 87 \% \text { of all drownings }\end{array}$ \\
\hline $\begin{array}{l}\text { Australia (Geelong), 1967-71; } \\
\text { Plueckhahn, 1972 }\end{array}$ & $\begin{array}{l}\text { "Accidental" drownings } \\
\text { Persons } \geqslant 16 \text { years; "boating" }\end{array}$ & \multicolumn{2}{|c|}{$\begin{array}{ll}n=? \text { (total number not known) } \\
\text { More than zero } 67 \% \\
>0.08 & 67 \% \\
>0.15 & 67 \%\end{array}$} & $\begin{array}{l}\text { Alcohol present in autopsy blood sample } \\
\text { Available for } 3 \text { (unknown \% of boating deaths, } \\
\text { but available for } 69 \% \text { of all drownings) }\end{array}$ \\
\hline
\end{tabular}

suggested that about $30 \%-40 \%$ (higher in some studies) of people on boats drink alcohol while on board, ${ }^{10} 20-24$ that men tend to drink more ${ }^{1020-222425}$ and behave in higher risk aquatic activities in association with drinking, ${ }^{22}$ than women, and that available boater training is inadequate. ${ }^{10} 112025-28$

There is little published information about public attitudes or understanding of alcohol's involvement in serious and fatal injuries sustained during recreational aquatic activity, with one United States study finding that many respondents to a mail survey reported that it was safe for passengers to drink more than boat operators, and that it was safe to drink more when the boat was at rest compared with when it was moving. ${ }^{26}$

\section{Contribution of alcohol to recreational aquatic activity injury}

In their review of alcohol and drowning literature published up to 1985, Howland and Hingson found that between $25 \%$ and $50 \%$ of adult persons who drowned unintentionally had used alcohol, but they also called for more information to be collected on alcohol use in involved persons who did not drown. ${ }^{5}$ A subsequent review by the same authors of 
Table 3 Published estimates of risk or relative risk of fatal injury in relation to recreational aquatic activities

\begin{tabular}{|c|c|c|c|c|}
\hline Population & Risk measure & Level & Risk & $95 \% \mathrm{Cl}$ \\
\hline $\begin{array}{l}\text { All accidental "recreational boating deaths" } \\
\text { occurring in Maryland and North Carolina } \\
\text { in the United States from 1990-98, } \\
\text { inclusive; Smith et al, 2001 }\end{array}$ & $\begin{array}{l}\text { RR of fatal injury in relation } \\
\text { to recreational boating }\end{array}$ & $\begin{array}{l}0.01 \mathrm{~g} / 100 \mathrm{ml} \\
0.05 \mathrm{~g} / 100 \mathrm{ml} \\
0.10 \mathrm{~g} / 100 \mathrm{ml} \\
0.25 \mathrm{~g} / 100 \mathrm{ml}\end{array}$ & $\begin{array}{r}1.3 \\
3.7 \\
10.4 \\
52.4\end{array}$ & $\begin{array}{l}1.2 \text { to } 1.4 \\
2.8 \text { to } 4.7 \\
6.9 \text { to } 15.7 \\
25.9 \text { to } 106.1\end{array}$ \\
\hline $\begin{array}{l}\text { Boating fatalities in California (includes non- } \\
\text { recreational activities); Mengert et al, } 1992^{45}\end{array}$ & RR of drowning & $\begin{array}{l}\text { More than zero } \\
0.10 \mathrm{~g} / 100 \mathrm{ml} \text { or greater }\end{array}$ & $\begin{array}{r}2.9 \\
10.6\end{array}$ & \\
\hline $\begin{array}{l}\text { Drowning deaths (includes non-recreational } \\
\text { activities); Smith and Houser, } 1994^{46}\end{array}$ & RR of drowning & $\begin{array}{l}>\text { Zero alcohol } \\
>0.10 \mathrm{~g} / 100 \mathrm{ml}\end{array}$ & $\begin{array}{r}4.6 \\
31.8\end{array}$ & $\begin{array}{l}1.6 \text { to } 13.1 \\
5.8 \text { to } 176\end{array}$ \\
\hline $\begin{array}{l}\text { Recreational boating deaths in Ohio; } \\
\text { Molberg et al, } 1993^{44}\end{array}$ & Proportion related to alcohol & $\begin{array}{l}\text { Alcohol "contributed" } \\
\text { Alcohol "caused" }\end{array}$ & $\begin{array}{l}7 \%-21 \% \\
7 \%\end{array}$ & \\
\hline $\begin{array}{l}\text { All recreational boating deaths in the } \\
\text { United States; US Coast Guard, } 2001^{42}\end{array}$ & Proportion related to alcohol & $\begin{array}{l}\text { Alcohol "involved" } \\
\text { Alcohol "caused" }\end{array}$ & $\begin{array}{l}31 \% \\
14 \%\end{array}$ & \\
\hline
\end{tabular}

literature up to 1991 found a similar range of values. ${ }^{4}$ Several relevant studies have been published since then, and their results remain consistent with the Howland and Hingson reviews. ${ }^{29-31}$

Most potentially relevant studies are not restricted to persons who were injured in the context of recreational aquatic activities. A recent review does focus on recreational aquatic activity, but not on drowning or alcohol, although these are included. ${ }^{6}$ The quality of information on alcohol involvement in individual studies ranges from poor to very good. These studies suggest that drowning is the overwhelming cause of death associated with recreational aquatic activity, that alcohol is detected in the blood of about $30 \%-$ $70 \%$ persons who drown in association with recreational aquatic activity, and that alcohol probably contributes to between $10 \%$ and $30 \%$ of all recreational drowning deaths. The useful results from the more relevant of these studies are summarised in table 1 for swimming (including surfing), ${ }^{232-39}$ and table 2 for boating. ${ }^{28} 32-3638-44$

\section{Measures of risk due to alcohol}

Very few direct measures of risk of serious or fatal injury related to aquatic recreational activities are available. Those that are available nearly all cover only drowning. The main available estimates are described here and summarised in table $3 .{ }^{28} 4244-46$

The best available information comes from a population based case referent study of drinking and recreational boating fatalities by Smith and co-workers. This study appears to have included all fatalities, but these were predominantly drowning deaths. The study found that alcohol use by the deceased person increased the risk of fatal injury associated with boating at all measurable levels of alcohol, ranging from an estimated relative risk

Table 4 Proposed preventive actions to decrease the risk of fatal injury in relation to alcohol and recreational aquatic activities

\begin{tabular}{|c|c|}
\hline Proposed action & References \\
\hline $\begin{array}{l}\text { Public service announcements by government agencies and community } \\
\text { based organisations warning about the dangers of alcohol use in } \\
\text { association with water recreation, and tailoring such messages to } \\
\text { swimming, boating, and/or fishing }\end{array}$ & $5,24,34,43$ \\
\hline $\begin{array}{l}\text { Eliminating or modifying advertisements that encourage the use of } \\
\text { alcohol during boating activities }\end{array}$ & $5,24,34$ \\
\hline Restricting the sale of alcoholic beverages at aquatic facilities & $5,24,54$ \\
\hline $\begin{array}{l}\text { Passage and enforcement of legislation restricting alcohol consumption } \\
\text { during water recreation activities }\end{array}$ & $2,5,24,33,40,44$ \\
\hline $\begin{array}{l}\text { Introduction of stiffer penalties for operating recreational boats under the } \\
\text { influence of alcohol }\end{array}$ & 51 \\
\hline Making licencee/server liability apply to drowning & 61 \\
\hline $\begin{array}{l}\text { Limiting the consumption of alcohol by anyone engaged in any form } \\
\text { of activity related to water }\end{array}$ & $12,41,49,50,54,56$ \\
\hline $\begin{array}{l}\text { Public education on the risks of drowning if alcohol is consumed while } \\
\text { involved in aquatic activities }\end{array}$ & $\begin{array}{l}2,3,11,20,21,23,26,33,35,36, \\
39,40,43,50,53,57,59-61\end{array}$ \\
\hline $\begin{array}{l}\text { Public education aimed at changing public acceptance of drinking while } \\
\text { involved in aquatic activities }\end{array}$ & 10,52 \\
\hline Public education of the potential benefits of alcohol control policies & 55 \\
\hline Including information on the risks of alcohol use in all training for boaters & $25,27,44$ \\
\hline Focusing on all boat occupants, not just the operators & $2,11,20,26,28,40,41,43$ \\
\hline Targeting adult males & $20,33,43$ \\
\hline Using a standardised sobriety test & 33,58 \\
\hline
\end{tabular}


Table 5 Areas for further research or action to decrease the risk of fatal injury in relation to alcohol and recreational aquatic activities

\begin{tabular}{ll}
\hline Proposed action & References \\
\hline $\begin{array}{l}\text { Developing a better understanding about the epidemiology of boating and/or } \\
\text { non-boating, alcohol related drowning incidents, including better measures of the } \\
\text { association between alcohol and drowning }\end{array}$ & $10,21,31,32$ \\
$\begin{array}{l}\text { Obtaining more information on drownings involving particular racial/ethnic groups } \\
\text { and women }\end{array}$ & 3 \\
$\begin{array}{l}\text { Obtaining information on the possible role of alcohol intake in persons supervising } \\
\text { children under } 6 \text { years of age who drown }\end{array}$ & 37 \\
$\begin{array}{l}\text { Obtaining more information on drownings through linkage of health, administrative, } \\
\text { and risk data sources }\end{array}$ & 3 \\
$\begin{array}{l}\text { Determining the effectiveness and acceptability of random sobriety checks for boat } \\
\text { operators }\end{array}$ & 20 \\
$\begin{array}{l}\text { Determining an appropriate permissible blood alcohol concentration or the need for } \\
\text { a "zero tolerance" approach regarding alcohol use and boating }\end{array}$ & 20 \\
$\begin{array}{l}\text { Measuring the impact of laws already in place prohibiting boating while intoxicated } \\
\text { Examining the feasibility of controls to limit alcohol consumption by swimmers, } \\
\text { especially those aged between } 25 \text { and } 40 \text { years, and males between } 20\end{array}$ & 32 \\
and 40 years & 33 \\
$\begin{array}{l}\text { Developing (national) guidelines for the best way to obtain and record information on } \\
\text { blood alcohol level in drowning deaths }\end{array}$ & 29 \\
$\begin{array}{l}\text { Ensuring that coroners determine the blood alcohol level for all persons } \\
\text { (10 years or older) who drown }\end{array}$ & 29,65 \\
\hline
\end{tabular}

(RR) of 1.3 (95\% confidence interval (CI) 1.2 to 1.4 ) at $0.010 \mathrm{~g} / 100 \mathrm{ml}, 10.6$ (95\% CI 6.9 to 15.7$)$ at $0.10 \mathrm{~g} / 100 \mathrm{ml}$ to $52(95 \% \mathrm{CI} 26$ to 106$)$ at $0.25 \mathrm{~g} / 100 \mathrm{ml}$. The relative risks were similar if fatalities (and the relevant controls) of people who were voluntarily swimming from a boat were excluded, and were similar for boat operators and boat passengers. ${ }^{28}$

The only other comparable study was a small study of boating fatalities in California, which found an odds ratio of 2.9 for any drinking, and 10.6 for blood alcohol levels above $0.10 \mathrm{~g} / 100 \mathrm{ml}$ (Mengert et $a l^{45}$ cited elsewhere ${ }^{26}{ }^{28}$ ). The remaining studies were either small $^{46}$ or provided only absolute measures of risk $^{42}{ }^{44}$ and appeared to have considerable methodological limitations.

\section{Trends in the role of alcohol}

Cummings and Quan applied the attributable percentages they derived to cases identified in coroners' records with nonzero blood alcohol levels in Washington State, in the United States. The study found that there was an $81 \%$ decline in drowning due to alcohol over the 20 years covered by the study, and that the percentage of all drowning due to alcohol fell from $50 \%$ to $22 \%$ over the 20 years. ${ }^{31}$ The reasons for the decline have been debated, but might include any of a decreased propensity to swim in settings where alcohol is more likely to be used, decreased use of alcohol, and bias due to missing data on alcohol. ${ }^{47} \mathrm{~A}$ similar study of the trends in the role of alcohol consumption and fatal "accidents" (including drowning) in Canada from 1950 to 1998 found "statistically significant" positive relationships between per capita alcohol intake and fatality rate for "falling accidents", "motor vehicle accidents" and "other accidents", but not for "drowning accidents" ${ }^{48}$

\section{Prevention strategies}

Many strategies have been suggested for decreasing the risk of alcohol related injury (particularly drowning) during aquatic activities. These are contained in many of the references already cited and are shown in table $4 .^{2} 35$ 10-12 20-28 33-36 39-41 43 44 49-61
However, few of these suggested strategies have been the subject of rigorous scientific evaluation, and drowning has been called the "final frontier" of injury prevention. ${ }^{62}$ Some intervention trials of limited relevance to alcohol and drowning have been published. All parents of children attending an emergency department at a paediatric tertiary referral hospital in the United States who were given printed information (which included mention of alcohol) on water safety recalled receiving instructions of some sort when surveyed one to two weeks later. ${ }^{63}$ Minimum drinking age laws do not appear to be an important policy initiative for preventing drowning in adolescents and young adults, based on a study of the number of drowning fatalities and the state minimum drinking age laws in the United States, although the authors did not rule out a small effect of the laws. ${ }^{64}$

Chochinov, in a review of boating fatalities in Canada, argues that alcohol is an important contributor to boating

\section{Key points}

- There is surprisingly little good quality epidemiological evidence regarding the effect of alcohol use on the risk of drowning during recreational aquatic activities.

- The percentage of drowning victims with a measurable blood alcohol concentration is of the order of $30 \%$ to $70 \%$.

- The percentage of drowning deaths attributed to alcohol use appears to be between $10 \%$ and $30 \%$.

- The risk of drowning increases with increasing blood alcohol concentration.

- Further research, with better data definitions and data collection, is required to confirm and characterise the risk relationship between alcohol and major types of recreational aquatic activity, to describe and quantify exposure, and to evaluate the efficacy of intervention programs. 
related drowning, and that the use of alcohol in association with the operation of a boat should be seen as socially irresponsible, as is drinking and driving. ${ }^{52}$ However, the focus on boat operators ("designated operators") in campaigns to decrease alcohol use in relation to boating activity has been criticised, because drinking passengers may be at risk regardless of the sobriety of the boat operator through the effects of alcohol on balance, judgment, swimming ability, and response to cold. ${ }^{112628}$ The authors also argue against focusing only on moving boats, since many boating fatalities occur when the boat is stationary or drifting: $24 \%$ in the United States in $2000 .^{42}$

In addition to the suggested prevention areas listed above, a number of areas for further research or action have been identified (table 5). These initiatives can be combined into a small number of themes, such as initiatives to discourage use of alcohol; impose penalties on persons who have high blood alcohol levels; focus on particular high risk groups; and obtain a better understanding of the risks of alcohol use and the benefits of prevention programs. ${ }^{3} 1020212931-333765$

\section{DISCUSSION}

Activities designed to decrease alcohol consumption in relation to recreational aquatic activity are based on a presumption that alcohol is a risk factor, and are thus generally accepted as being appropriate preventive activities. Anecdotal evidence and cases series studies strongly support the presumption that alcohol use is a problem, but it is really only the case referent study by Smith and co-workers of fatalities related to recreational boating that provides robust evidence of the extent of increased risk associated with various levels of blood alcohol. ${ }^{28}$

The overall quality of the studies, and in particular their usefulness in the current consideration of drowning in recreational aquatic activities, varied considerably. The most useful studies had a study group that was a close match to the groups of main interest (recreational swimming or boating), clearly stated the subject numbers and the number with valid blood alcohol measurements, had a high proportion of subjects with valid blood alcohol measurements, clearly stated the criteria for inclusion and exclusion of blood alcohol measurements, and provided numeric values for the blood alcohol measurements. There was insufficient information to provide useful insight into the involvement of alcohol in areas of aquatic recreation apart from swimming and boating resulting in drowning, such as underwater diving and rock fishing, or into any possible differences with age and gender, apart from the apparent tendency of men to drink more alcohol in relation to aquatic activity, as mentioned earlier.

The rate of autopsy in drowning varies widely between regions, as does the proportion of persons for whom blood alcohol levels are assessed, either electively or as mandated by legislation. Most of the studies reviewed here had a significant minority, or even a majority, of cases with missing blood alcohol values. Where the percentage was known, valid blood alcohol values were usually available for between $50 \%$ and $80 \%$ of subjects. A lack of valid blood alcohol values, either because the body was not recovered, the body was significantly decomposed, the body was not recovered for several days or the specimen was not taken at autopsy, can potentially bias any study in this area. This is because particular drowning circumstances may be more likely to both involve alcohol and to result in long delays in recovery of the body. ${ }^{19}$ Therefore, it is important to minimise the number of subjects with missing blood alcohol results. Since a considerable proportion of subjects in many studies would need to be excluded if the blood specimen needed to be taken within 24 hours, as recommended by some, ${ }^{18}$ techniques for adjusting blood alcohol measurements in bodies found between 12 hours and seven days after death have been used. ${ }^{19}$

\section{PRIORITIES FOR FUTURE WORK}

Information about the use of alcohol in the context of aquatic activities is inadequate for most countries for reliable estimation of the proportion of drowning attributable to alcohol, or to provide a basis for information based policy response (for example, monitoring effects of programs to discourage drinking before swimming or while boating). Effective prevention is likely to result from a thorough understanding of aquatic activities, alcohol use, and the way that these interact. Several forms of information can contribute to this understanding. Case-control studies can enable comparison of characteristics of participants in aquatic activities (including their use of alcohol) who did and did not drown (or experience another undesirable outcome). Surveys of participants can improve understanding of patterns of use of alcohol during aquatic activities, and about the knowledge and attitudes of participants to such use. Trials can be designed to test and evaluate the effectiveness of interventions designed to reduce alcohol related harm during aquatic activities. In addition, better surveillance at the population level is required, especially in developing countries, of the extent and level of alcohol involvement. This surveillance requires a high proportion of drowning cases to have autopsies, and a high proportion of drowning cases to have valid blood alcohol measurements.

The existing evidence, argument by analogy with literature on risk due to alcohol in other settings (for example, motor vehicle operation), and a cautious approach provide a basis for arguing against any use of alcohol during, or in relevant periods before, aquatic activities. However, the specific evidence base warrants expansion, particularly to confirm apparent elevation of risk at low blood alcohol levels (that is, $0.05 \mathrm{~g} / 100 \mathrm{ml}$ and lower) and to broaden the range of types of aquatic activity for which evidence on alcohol and risk is available. Existing studies provide relevant examples of how such investigations could be undertaken. ${ }^{28}{ }^{46}$ Table 5 lists a number of possible prevention initiatives. These and other approaches, such as legislation using the same blood alcohol limits for boat operators as for motor vehicle drivers, training in responsible serving of alcohol (on and off-shore), availability of lifesaving equipment, changes in practice for night-time aquatic activity, and policy/practice changes for operators of marine facilities and licensed venues, all appeal as potentially effective. However, without proper evaluation studies of interventions, it is difficult to confidently recommend one or more as likely to be effective in decreasing the contribution that alcohol makes to drowning.

\section{CONCLUSIONS}

Alcohol appears to be widely used in association with recreational aquatic activity, and to be an important risk factor for drowning associated with recreational aquatic activity. Information is lacking in many areas concerning alcohol use in relation to recreational aquatic activity. The most important of these relate to understanding the attitudes and alcohol use of persons engaging in recreational aquatic activity, characterising the increased risk (and the attributable risk due to alcohol) of drowning that arises from different levels and types of alcohol use, and evaluating the many prevention approaches that have been suggested or already implemented.

\section{ACKNOWLEDGEMENTS}

This paper is based on work conducted by the authors as part of a project funded by the Australian Department of Health and Ageing. 
The project was conducted in support of the objective of the Plan for Action 2001 to 2003-04 of the Department of Health and Aged Care National Alcohol Strategy to reduce injuries and fatalities in the aquatic environment. The authors wish to thank Stacey Wendt for obtaining many of the references used in the literature review.

\section{Authors' affiliations}

T R Driscoll, School of Public Health, University of Sydney and ELMATOM Pty Ltd, New South Wales, Australia

J A Harrison, M Steenkamp, Research Centre for Injury Studies, Flinders University, Bedford Park, South Australia

Disclaimer: The views in this publication are those of the authors.

\section{REFERENCES}

1 Peden M, McGee K, Krug E. Injury: a leading cause of the global burden of disease, 2000. Geneva: World Health Organisation, 2002.

2 Browne M, Lewis-Michl E, Stark A. Unintentional drownings among New York State residents, 1988-1994. Public Health Rep 2003;118:448-58.

3 Bell N, Amoroso P, Yore M, et al. Alcohol and other risk factors for drowning among male active duty US army soldiers. Aviat Space Environ Med 2001;72:1086-95.

4 Hingson R, Howland J. Alcohol and non-traffic unintended injuries. Addiction 1993;88:877-83.

5 Howland J, Hingson R. Alcohol as a risk factor for drownings: a review of the literature (1950-1985). Accid Anal Prev 1988:20:19-25.

6 Chalmers D, Morrison L. Epidemiology of non-submersion injuries in aquatic sporting and recreational activities. Sports Med 2003;33:745-70.

7 National Library of Medicine. PubMed. Accessed September-November 2002, October 2003 (http://www.ncbi.nlm.nih.gov/entrez/query.fcgi).

8 Gooden B. Drowning and the diving reflex in man. Med J Aust 1972;ii:583-7.

9 Gooden B. Drowning and alcohol. Med J Aust 1984;141:478.

10 Howland J, Mangione T, Hingson R, et al. A pilot survey of aquatic activities and related consumption of alcohol, with implications for drowning. Public Health Rep 1990;105:415-19.

11 Howland J, Smith G, Mangione T, et al. Missing the boat on drinking and boating. JAMA 1993;270:91-2.

12 Bross M, Clark J. Near-drowning. Am Fam Physician 1995:51:1545-8.

13 Driscoll T, Harrison J, Steenkamp M. Alcohol and water safety. Canberra: Department of Health and Ageing, 2003.

14 Johnstone J. Alcohol and drowning. Med J Aust 1985;142:234-5.

15 O'Neal C, Poklis A. Postmortem production of ethanol and factors that influence interpretation: a critical review. Am J Forensic Med Pathol 1996;17:18-20.

16 Plueckhahn V, Ballard B. Factors influencing the significance of alcoho concentrations in autopsy blood samples. Med J Aust 1968;i:939-43.

17 Plueckhahn V. The significance of blood alcohol levels at autopsy. Med J Aust $1967 ; 2: 118-24$.

18 Wintemute G, Teret S, Kraus J, et al. Alcohol and drowning: an analysis of contributing factors and a discussion of criteria for case selection. Accid Anal Prev 1990:22:291-6.

19 Hadley J, Smith G. Evidence for an early onset of endogenous alcohol production in bodies recovered from the water: implications for studying alcohol and drowning. Accid Anal Prev 2003;35:763-9.

20 Logan P, Sacks J, Branche C, et al. Alcohol-influenced recreational boat operation in the United States, 1994. Am J Prev Med 1999:16:278-82.

21 Centers for Disease Control and Prevention. Alcohol use and aquatic activities-Massachusetts, 1988. MMWR Morb Mortal Wkly Rep 1990;39:332-4.

22 Howland J, Hingson R, Mangione T, et al. Why are most drowning victims men? Sex differences in aquatic skills and behaviours. Am J Public Health 1996;86:93-6

23 Ciraulo D, Smith P, Ciraulo S. A trauma systems assessment of boating safety: a comparison of commercial and recreational boating practices. Am Surg 2000:66:604-7.

24 Centers for Disease Control and Prevention. Alcohol use and aquatic activities - United States, 1991. MMWR Morb Mortal Wkly Rep 1993:42:675, 681-3.

25 Glover E, Lane S, Wang M. Relationship of alcohol consumption and recreational boating in Beaufort County, North Carolina. J Drug Educ 1995;25: 149-57.

26 Howland J, Mangione T, Minsky S. Perceptions of risk of drinking and boating among Massachusetts boaters. Public Health Rep 1996;111:372-7.

27 Bell N, Howland J, Mangione T, et al. Boater training, drinking and boating, and other unsafe boating practices. J Drug Educ 2000;30:467-82.
28 Smith G, Keyl P, Hadley J, et al. Drinking and recreational boating fatalities: a population-based case-control study. JAMA 2001;286:2974-80.

29 Warner M, Smith G, Langley J. Drowning and alcohol in New Zealand: what do the coroner's files tell us? Aust N Z J Public Health 2000;24:387-90.

30 Smith G, Branas C, Miller T. Fatal nontraffic injuries involving alcohol: a metaanalysis. Ann Emerg Med 1999;33:659-68.

31 Cummings P, Quan L. Trends in unintentional drowning: the role of alcohol and medical care. JAMA 1999;281:2198-202.

32 Wintemute G, Kraus J, Teret S, et al. The epidemiology of drowning in adulthood: implications for prevention. Am J Prev Med 1988:4:343-8.

33 Canadian Red Cross Society. An analysis of drownings and other waterrelated injury fatalities in Canada for 1999. Montreal: Canadian Red Cross Society, 2000.

34 Dietz P, Baker S. Drowning. Epidemiology and prevention. Am J Public Health 1974:64:303-12.

35 Plueckhahn V. The aetiology of 134 deaths due to "drowning" in Geelong during the years 1957 to 1971. Med J Aust 1972;ii: 1183-7.

36 Plueckhahn V. Alcohol and accidental drowning: a 25-year study. Med J Aust 1984;141:22-5.

37 Davis S, Smith L. The epidemiology of drowning in Cape Town: 1980-1983. $S$ Afr Med J 1985;68:739-42.

38 Patetta M, Biddinger P. Characteristics of drowning deaths in North Carolina. Public Health Rep 1988;103:406-11.

39 Steensberg J. Epidemiology of accidental drowning in Denmark 1989-1993. Accid Anal Prev 1998;30:755-62.

40 Browne M, Lewis-Michl E, Stark A. Watercraft-related drownings among New York State residents, 1988-1994. Public Health Rep 2003;118:459-63.

41 Centers for Disease Control and Prevention. Drowning-Lovisiana, 1998. MMWR Morb Mortal Wkly Rep 2001;50:413-14.

42 United States Coast Guard. Boating statistics-2000. Washington, DC: US Coast Guard, 2001

43 Lunetta P, Penttila A, Sarna S. Water traffic accidents, drowning and alcohol in Finland, 1969-1995. Int J Epidemiol 1998:27:1038-43.

44 Molberg P, Hopkins R, Paulson J, et al. Fatal incident risk factors in recreational boating in Ohio. Public Health Rep 1993;108:340-6.

45 Mengert P, Sussman E, DiSario R. A study of the relationship between the risk of fatality and blood alcohol concentration of recreational boat operators. Washington, DC: US Coast Guard, 1992.

46 Smith G, Houser J. Risk factors for drowning: a case-control study (abstract). 122nd Annual meeting of the American Public Health Association. Washington, DC: American Public Health Association, 1994.

47 Smith G, Howland J. Declines in drowning. Exploring the epidemiology of favourable trends (editorial). JAMA 1999;281:2245-7.

48 Skog O. Alcohol consumption and fatal accidents in Canada, 1950-98. Addiction 2003:98:883-93.

49 Adams A. The descriptive epidemiology of drowning accidents. Med J Aust 1966;ii: 1257-61.

50 Centers for Disease Control and Prevention. North Carolina drownings, 1980-1984. MMWR Morb Mortal Wkly Rep 1986;35:635-8.

51 Centers for Disease Control and Prevention. Recreational boating fatalitiesOhio, 1983-1986. JAMA 1987;258:22, 24.

52 Chochinov A. Alcohol "on board", man overboard-boating fatalities in Canada. CMAJ 1998;159:250-60.

53 Fenner $\mathbf{P}$, Harrison $S$, Williamson $j$, et al. Success of surf lifesaving resuscitations in Queensland, 1973-1992. Med J Aust 1995:163:580-3.

54 Fenner P. Drowning awareness. Prevention and treatment. Aust Fam Physician 2000;29:1045-9.

55 Girasek D. Public beliefs about the preventability of unintentional injury deaths. Accid Anal Prev 2001:33:455-65.

56 Gulaid J, Sattin R. Drownings in the United States, 1978-1984. MMWR Morb Mortal Wkly Rep 1988;37:27-33.

57 Mackie I. Patterns of drowning in Australia, 1992-1997. Med J Aust 1999;171:587-90.

58 McKnight A, Lange J, McKnight A. Development of a standardized boating sobriety test. Accid Anal Prev 1999:31:147-52.

59 Pearn J. Drowning and alcohol. Med J Aust 1984;141:6-7.

60 Scher A. Diving injuries of the spinal cord. S Afr Med J 1992;81:291-2.

61 Wintemute G, Kraus J, Teret S, et al. Drowning in childhood and adolescence: a population-based study. Am J Public Health 1987;77:830-2.

62 Pless B. The challenge of drowning prevention (editorial). Inj Prev 1997; $3: 237-8$

63 Quan L, Bennett E, Cummings P, et al. Do parents value drowning prevention information at discharge from the emergency department? Ann Emerg Med 2001;37:382-5.

64 Howland J, Birckmayer J, Hemenway D, et al. Did changes in minimum age drinking laws affect adolescent drowning (1970-90)? Inj Prev 1998;4:288-91.

65 Browne M, Lewis-Michl E, Stark A. Investigation and reporting practices for drownings: implications for injury prevention research in New York state. Am J Forensic Med Pathol 2002;23:398-401. 